Doc. dr. sc. Marija Pleić, docentica ${ }^{1}$

Pravni fakultet Sveučilišta u Splitu

Doc. dr. sc. Ivan Vukušić, docent ${ }^{2}$

Pravni fakultet Sveučilišta u Splitu

\title{
NEKA PITANJA SURADNJE DRŽAVE I KATOLIČKE CRKVE U PODRUČJU KAZNENOG PRAVA ${ }^{3}$
}

\author{
UDK: $322: 343$ \\ Izvorni znanstveni rad \\ Primljeno: 15. I. 2020.
}

DOI: $10.31141 / z r p f s .2020 .57 .137 .759$

Predmet je ovog rada analiza odnosa države i Katoličke crkve u području kaznenog prava. Nakon izlaganja o temeljnim načelima odnosa države i Crkve, autori se bave pobliže pitanjem suradnje u kaznenom postupku u odnosu na obvezu prijavljivanja kaznenih djela, obvezu obavještavanja crkvenih vlasti o provođenju istrage protiv klerika te specifičan položaj vjerskog ispovjednika u kaznenom postupku u svojstvu svjedoka. U četvrtom poglavlju ispituju se granice suradnje države i Crkve u kontekstu Kaznenog zakona, konkretno putem analize kaznenih djela neprijavljivanja počinjenog kaznenog djela te pomoći počinitelju nakon počinjenog kaznenog djela. Također, analizira se doseg načela nepovredivosti ispovjedne tajne u kaznenom pravu i odnos prema kaznenom djelu neovlaštenog otkrivanja profesionalne tajne. Autori zaključuju o nužnosti učinkovite međusobne suradnje države i Crkve u slučajevima uključenosti klera u kazneni postupak, nužnosti pravodobnog prijavljivanja kaznenih djela te o obvezi apsolutnog poštovanja načela nepovredivosti ispovjedne tajne.

Ključne riječi: istraga, ispovjedna tajna, kanonski postupak, kaznena prijava, kazneni postupak, neprijavljivanje kaznenog djela

1 Doc. dr. sc. Marija Pleić, docentica na Katedri za kazneno procesno pravo, Pravni fakultet Sveučilišta u Splitu, Domovinskog rata 8, 21000 Split, e- mail: marija.pleic@ pravst.hr.

2 Doc. dr. sc. Ivan Vukušić, docent na Katedri za kazneno pravo, Pravni fakultet Sveučilišta u Splitu, Domovinskog rata 8,21000 Split, e-mail: ivukusic@pravst.hr.

3 Ovaj rad temelji se na izlaganju koje su autori izložili pod naslovom Kanonski kazneni postupak i suradnja s državnim vlastima na XIII. Međunarodnom simpoziju crkvenih pravnika „Spolno zlostavljanje maloljetnika. Odgovor Crkve u svjetlu kanonskog prava" koji se održao u Malinskoj na otoku Krku 11. i 12. listopada 2019. godine. 


\section{UVOD}

Odnos Republike Hrvatske i Katoličke crkve ${ }^{4}$ karakterizira načelo odvojenosti uz međusobnu suradnju, ${ }^{5}$ a ostvaruje se kroz tzv. konkordatski sustav. ${ }^{6}$ Sveta Stolica i Republika Hrvatska uredile su ugovorima svoje pravne odnose kao i druga otvorena pitanja iz različitih sfera društvenog života ${ }^{7}$ na temelju Ustava Republike Hrvatske koji proklamira spomenuta načela u čl. 40. i 41., ${ }^{8}$ te sa strane Svete Stolice, na dokumentima Drugog vatikanskog sabora i na odredbama kanonskog prava. ${ }^{9}$ Temeljni pravni akt koji regulira pravne odnose između Republike Hrvatske i Svete Stolice, po svojoj snazi iznad zakona jest Ugovor o pravnim pitanjima između Svete Stolice i Republike Hrvatske. Sukladno čl. 1. ovog Ugovora, Republika Hrvatska i Sveta Stolica, potvrđujući da su Država i Katolička crkva, svaka u svom poretku, neovisne i samostalne, obvezuju se da će u međusobnim odnosima potpuno poštovati to načelo te da će međusobno surađivati u brizi za cjelovit duhovni i materijalni razvoj čovjeka i u promicanju općega dobra. Ova odredba i načela izražena u njoj polazišna su točka za analizu pravnog odnosa države i Crkve općenito, ali i konkretno u području kaznenog prava.

U središtu ovog rada pitanje je suradnje države i Crkve tijekom kaznenog postupka s obzirom na različite (procesne) uloge u kojima se klerici mogu pojaviti, analiza kaznenopravne odgovornosti klerika za neprijavljivanje kaznenog djela i pravni status ispovjedne tajne u kontekstu kaznenog zakonodavstva. ${ }^{10}$ Uvodno je potrebno osvrnuti se na pravne izvore relevantne za kazneno materijalno i kazneno procesno pravo, kako civilne tako i crkvene. Kaznena djela kao ponašanja kojima

${ }^{4}$ U nastavku rada za instituciju Katoličke crkve koristit će se skraćenica Crkva.

5 Načelo odvajanja države i Crkve ima svoje kršćanske korijene u Isusovoj izreci „Podajte dakle caru carevo, a Bogu Božje“" (Mt 22, 21) iz koje su se razvili različiti modeli primjene tog načela. Opš. Eterović, N., Sveta Stolica i Hrvatska, Priznanje - Ugovori - Suradnja, Kršćanska sadašnjost, Zagreb, 2019., str. $184,188,226$.

6 Radi se o sustavu koji se temelji na sklapanju dvostranih međunarodnih ugovora (s obzirom na međunarodnopravni subjektivitet Svete Stolice). Premda ugovori Republike Hrvatske sa Svetom Stolicom ne predstavljaju konkordat u pravom smislu te riječi, može se govoriti o konkordatima u širem smislu riječi. Opš. Zec, S., „Pravni temelji prisutnosti i djelovanja Crkve u javnosti u Republici Hrvatskoj“, Riječki teološki časopis, god. 18 (2010.), br. 2, str. 393. Također Eterović, N., op. cit. u bilj. 5, str. 188-189.

7 Republika Hrvatska i Sveta Stolica sklopile su sljedeće ugovore: Ugovor o pravnim pitanjima (Narodne novine, Međunarodni ugovori, br. 3/1997), Ugovor o dušobrižništvu katoličkih vjernika, pripadnika oružanih snaga i redarstvenih službi Republike Hrvatske (NN MU br. 2/1997), Ugovor o suradnji na području odgoja i kulture, (NN MU, br. 2/1997), Ugovor o gospodarskim pitanjima (NN MU, br. 18/1998).

8 Ustav RH u članku 40. jamči slobodu savjesti i vjeroispovijedi i slobodno javno očitovanje vjere ili drugog uvjerenja, a u čl. 41. utvrđuje da su sve vjerske zajednice jednake pred zakonom i odvojene od države. Ustav Republike Hrvatske, Narodne novine br. 56/90, 135/97, 113/00, 124/00, 28/01, 41/01, 55/01, 76/10, 85/10, 5/14.

9 Pastoralna konstitucija Drugoga vatikanskog koncila „Gaudium et spes“ ističe kako su politička zajednica i Crkva, svaka na svom području, neovisne jedna o drugoj i autonomne (toč. 67), Drugi Vatikanski sabor, Pastoralna konstitucija (1) »Gaudium et spes« (Radost i nada) o Crkvi u suvremenom svijetu, 7. XII. 1965.

10 Pravni status klerika stječe se valjanim primanjem sakramenta svetog reda (đakon, prezbiter i

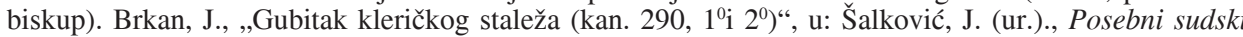
postupci i postupanja, Zagreb: Glas Koncila, 2010., str. 166-167. 
se povređuju temeljne društvene vrijednosti zajamčene Ustavom i međunarodnim pravom kažnjavaju se u okviru pravnog poretka Republike Hrvatske sukladno Kaznenom zakonu ${ }^{11} \mathrm{u}$ kaznenim postupcima propisanima Zakonom o kaznenom postupku. ${ }^{12}$ S druge pak strane, Zakonik kanonskog prava iz 1983 . godine ${ }^{13}$ propisuje ponašanja koja se sukladno kanonskom pravu smatraju kažnjivim djelima (kan. 1364 do 1399) kao i tijek kaznenog postupka koji se vodi povodom počinjenih kažnjivih djela (kanoni 1717 do 1731). Pored toga, u okviru Crkve doneseni su dokumenti koji se na poseban način dotiču kaznenopravnih pitanja, konkretno, prijave i postupanja povodom počinjenja kaznenih djela spolnog zlostavljanja maloljetnika počinjenih od strane klera, a s obzirom na opasnost i težinu ovih djela i težinu posljedica posebice u slučajevima kada su počinjena od strane vjerskih službenika. Naime, zalječenje rana koje su nastale u slučajevima prikrivanja kaznenih djela spolnog zlostavljanja od strane klerika u nastojanju čuvanja ugleda Crkve,${ }^{14}$ te odgovarajuća zaštita žrtava i društva u cjelini moguća je samo uz izraženu spremnost na sankcioniranje pripadnika klera i otvorenost za učinkovitu suradnju s državnim tijelima. U tom smjeru, povodom poziva Kongregacije za nauk vjere, ${ }^{15}$ Hrvatska biskupska konferencija (HBK) donijela je Smjernice za postupanje u slučajevima spolnog zlostavljanja maloljetnika od strane klera koje je Kongregacija potvrdila 21. prosinca 2015. godine. ${ }^{16}$ Značajan iskorak u smjeru prevencije i borbe protiv spolnog zlostavljanja, jačanja odgovornosti i sankcioniranja zataškavanja i propusta crkvenih tijela predstavlja apostolsko pismo pape Franje u obliku motu propija Vos estis lux mundi (Vi ste svjetlo svijeta) iz svibnja 2019. godine. ${ }^{17}$ Ovaj dokument utvrđuje nova pravila za postupanje povodom počinjenih kaznenih djela zlostavljanja od strane klera, uspostavlja obvezu prijave tih djela kao i obvezu uspostave javno dostupnih sustava prijave spolnog zlostavljanja.

U radu koji slijedi osvrnut ćemo se na navedene izvore crkvenog prava koji propisuju postupanje crkvenih tijela i osoba povodom počinjenih kažnjivih djela koja su ujedno i kaznena djela te analizirati njihov odnos s kaznenim i kaznenoprocesnim zakonodavstvom Republike Hrvatske i obvezama koje proizlaze iz istog.

11 Kazneni zakon, Narodne novine br. 125/11, 144/12, 56/15, 61/15, 101/17, 118/18.

12 Zakon o kaznenom postupku, Narodne novine br. 152/2008, 76/2009, 80/2011, 91/2012, 143/2012, 56/2013, 145/2013, 152/2014, 70/2017.

13 Codex Iuris Canonici, auctoritate Ioannis Pauli PP. II promulgatus, Acta Apostolicae Sedis, 75 II (1983.), hrvatski prijevod: Zakonik kanonskoga prava, proglašen vlašću pape Ivana Pavla II., s izvorima, Glas Koncila - Zagreb, 1996.

14 U tom smislu Matulić podsjeća da su ljudsko dostojanstvo, čast i ugled osobe, a naročito one ranjive i povjerene brizi odraslih, važniji od časti i ugleda bilo koje institucije. Matulić, T., „Neki najrecentniji aspekti fenomena pedofilije u Crkvi“, Bogoslovska smotra, 88 (2018.) 4, str. 913.

15 Motu proprijem pape Ivana Pavla II., Sacramentorum Sanctitatis Tutela, iz 2001. godine, zlostavljanje maloljetnika (mlađih od osamnaest godina) izrijekom je predviđeno kao teško kažnjivo djelo (graviora delicta) čije je kažnjavanje u nadležnosti Kongregacije za nauk vjere. Godine 2011. Kongregacija za nauk vjere uputila je okružno pismo biskupskim konferencijama sa zahtjevom da izrade smjernice za postupanje u slučajevima zlostavljanja maloljetnika.

16 Tekst Smjernica dostupan je na mrežnoj stranici HBK: URL=http://hbk.hr/dokumenti-hbk/ smjernice-za-postupanje-u-slucajevima-spolnoga-zlostavljanja-maloljetnika-od-strane-klerika.

17 Apostolsko pismo u formi motu proprija pape Franje Vos estis lux mundi od 7. svibnja 2019. godine, stupilo na snagu 1. srpnja 2019. godine. 


\section{TEMELJNA NAČELA ODNOSA CRKVE I DRŽAVE U PODRUČJU KAZNENOG PRAVA}

\subsection{Načelo neovisnosti kanonskog i državnog kaznenog postupka}

S obzirom na to da su država i Crkva svaka u svom poretku neovisne i samostalne, to su i postupci koje svaka vodi sukladno svom pravnom poretku također neovisni. Pitanje odnosa kanonskog i državnog kaznenog postupka kao i odnosa i suradnje tijela koja sudjeluju u ovim postupcima na osobit način otvara se u slučajevima kada klerik počini kazneno djelo koje je istovremeno predviđeno kao kažnjivo djelo po crkvenom pravu. Naime, pojedina kaznena djela propisana Kaznenim zakonom ujedno se sankcioniraju i kao povrede crkvenog prava. Zakonik kanonskog prava tako propisuje, inter alia, kažnjiva djela protiv šeste Božje zapovijedi ${ }^{18}$ od kojih se pojedina mogu podvesti pod glavu kaznenih djela protiv spolne slobode te glavu kaznenih djela zlostavljanja i iskorištavanja djece iz Kaznenog zakona Republike Hrvatske, a predviđaju se crkvene sankcije i za kažnjiva djela protiv ljudskog života i slobode. ${ }^{19}$ Vođenje jednog kaznenog postupka pritom ne isključuje drugi. Riječ je o dva odvojena načina utvrđivanja kažnjivih radnji i izricanja sankcija, crkveni put, sukladno normama kanonskoga prava i civilni put, sukladno normama kaznenoga prava pojedine države. ${ }^{20}$ Ova odvojenost proizlazi iz činjenice da kaznena odgovornost sukladno zakonodavstvu RH i odgovornost po kanonskom pravu imaju različite pravne temelje, izvore, svrhu, te se u konačnici razlikuju po svojoj prirodi, sadržaju i svrsi i sankcije koje mogu biti izrečene za takva nedjela.

I Smjernice HBK-a referiraju se na načelo neovisnosti kanonskog i državnog kaznenog postupka iz čega dalje proizlazi da se ordinarij ${ }^{21}$ ne može pozivati na akt, pravomoćne ili nepravomoćne odluke donesene u državnome postupku, kako bi se izuzeo od obveze donošenja vlastite procjene i/ili da bi te odluke uzeo kao osnovu u provedbi kanonskoga postupka. Osim toga, ako i nije u tijeku kazneni postupak prema državnomu pravu, ordinarij je također dužan bez odlaganja pristupiti procjeni vjerodostojnosti (u skladu s kan. 1717) kad dobije dojavu o mogućim zlostavljanjima, te, ako je potrebno, provesti prethodnu istragu i primijeniti primjerene zaštitne

18 Šesta Božja zapovijed: Ne sagriješi bludno! Kanon 1395 §2 „Klerik koji drukčije pogriješi protiv šeste Božje zapovijedi, ako je naime kažnjivo djelo počinjeno prisilom ili prijetnjama ili javno ili s osobom mlađom od šesnaest godina.“ Motu proprijem pape Ivana Pavla II. Sacramentorum Sanctitatis Tutela dob od 16 godina iz kan. 1395 § 2 podignuta je na 18 godina. Opš. o ovim kažnjivim djelima v. Šalković, J., „Kažnjiva djela klerika protiv šeste Božje zapovijedi (kan. 1395)“, Bogoslovska smotra, 79 (2009.) 2, str. 257. i dr.

19 Kan. 1397 i 1398.

20 Šalković, J., op. cit. u bilj. 18, str. 260.

21 Sukladno kan. $134-\S 1$. Zakonika kanonskog prava pod nazivom ordinarija razumijevaju se u pravu, osim rimskog prvosvećenika, dijecezanski biskupi i drugi koji, iako samo privremeno, stoje na čelu neke partikularne Crkve ili zajednice s njom izjednačene prema odredbi kan. 368, kao i oni koji u njima imaju opću redovitu izvršnu vlast, naime generalni i biskupski vikari; isto tako, za svoje podložnike, viši poglavari redovničkih kleričkih ustanova papinskoga prava i kleričkih družba apostolskoga života papinskoga prava, koji imaju redovitu barem izvršnu vlast. 
mjere. ${ }^{22}$ Dakle, nadležne crkvene vlasti dužne su postupati po odredbama crkvenog prava neovisno o odluci civilnih vlasti u kaznenom postupku. S druge strane, u slučajevima kada državna tijela još nisu započela kazneni postupak odnosno nemaju saznanja o počinjenom kaznenom djelu, upravo provođenje prethodne istrage $u$ kanonskom postupku odnosno reakcija crkvenih tijela može imati ključnu ulogu za pokretanje kaznenog progona od strane državnog odvjetništva. ${ }^{23}$

\subsection{Načelo suradnje države i Crkve}

Iz čl. 1. Ugovora o pravnim pitanjima, osim načela neovisnosti i samostalnosti, proizlazi i načelo međusobne suradnje. Kada je riječ o području kaznenog prava, međusobna suradnja u promicanju općeg dobra o kojoj govori spomenuta odredba trebala bi podrazumijevati i suradnju u borbi protiv onih ponašanja koja povređuju temeljne društvene vrijednosti, odnosno suradnju s ciljem sprečavanja kaznenih djela, otkrivanja i kažnjavanja počinitelja pogotovo kada se radi o ponašanjima koja se sankcioniraju i po zakonodavstvu Republike Hrvatske i po crkvenom pravu. ${ }^{24}$ Izražena spremnost za suradnju od strane Crkve može pridonijeti otkrivanju i kažnjavanju počinitelja kaznenih djela, a time i učinkovitijoj primjeni državnog zakonodavstva. Istovremeno, učinkovita primjena kaznenog zakonodavstva RH može pomoći uspješnijem ostvarenju vlastitog poslanja Crkve time što će pravodobno i na odgovarajući način sankcionirati pripadnike klera koji se ogriješe o državna i crkvena pravila. ${ }^{25}$

Premda je Crkva neovisna u svom poretku, fizičke i pravne osobe koje djeluju u okviru Crkve na području Republike Hrvatske podliježu zakonodavstvu Republike Hrvatske i sudbenosti njezinih sudbenih tijela. Stoga crkveni propisi koji reguliraju prijavu i postupanje povodom počinjenih kažnjivih djela ne idu za izuzimanjem crkvenih tijela i osoba od obveza koje proizlaze iz civilnog zakonodavstva već se naglašava važnost suradnje i postupanja u skladu s državnim zakonima. ${ }^{26}$

Tako se u čl. 19. Motu prorija Vos estis lux mundis ističe da se odredbe tog dokumenta primjenjuju ne dovodeći u pitanje prava i obveze ustanovljene državnim zakonima, posebno ona koja se odnose na obvezu prijavljivanja nadležnim državnim vlastima. Dakle, neovisno o propisanom postupku prijavljivanja i istraživanja kažnjivih djela klera od strane crkvenih tijela, ta su tijela dužna prijaviti kazneno

22 Toč. 6. Smjernica HBK-a.

23 Opširnije infra 3.1.

24 Kako Krišto navodi, suradnja između države i Crkve ne počiva na jasnom razlučivanju utjecajnih sfera nego je to praktična suradnja u radu za dobrobit građana u kojoj svaki partner pridonosi nešto od svog bogatstva. Krišto, J., „Katolička crkva u totalitarizmu 1945. - 1990.“, Razmatranja o Crkvi u Hrvatskoj pod komunizmom, Zagreb, 1997., str. 32.

25 Tako Eterović objašnjava da je pomoću pravednih državnih zakona moguće spriječiti zloporabu religije pojedinih članova Crkve na raznim područjima djelovanja, među ostalim i možebitnim kriminalnim djelatnostima poput seksualnog zlostavljanja maloljetnika. Eterović, N., op. cit. u bilj. 5, str. 197.

26 Usp. Šalković, J., op. cit. u bilj. 18, str. 260. 
djelo u skladu s važećim domaćim zakonodavstvom. ${ }^{27}$ Također, i Smjernice HBK-a ističu važnost suradnje ordinarija s državnim vlastima u slučaju kad je za kažnjiva djela koja su predmet ovih Smjernica, pokrenut kazneni postupak prema državnome pravu. Ta se suradnja mora odvijati u okviru mjerodavnosti dviju strana i u skladu s propisima Republike Hrvatske i odredbama Ugovora o pravnim pitanjima između Svete Stolice i Republike Hrvatske. ${ }^{28}$ Ova suradnja pretpostavlja ponajprije dužnost prijave kaznenih djela u skladu s čl. 204. ZKP-a.

U nastavku rada analizirat ćemo podrobnije pojedine aspekte suradnje u okviru kaznenog postupka s obzirom na različita svojstva u kojima se pripadnici klera mogu pojaviti u kaznenom postupku.

\section{SURADNJA CRKVE S TIJELIMA KAZNENOG POSTUPKA}

\subsection{Podnošenje kaznene prijave od strane crkvenog tijela ili osobe}

Državni odvjetnik može započeti kazneni progon na temelju kaznene prijave fizičke ili pravne osobe ili na temelju vlastitog saznanja (ako je do njega dopro glas) o kaznenom djelu za koje se progon vrši po službenoj dužnosti. ${ }^{29}$ Kaznena prijava definira se kao pisana, usmena ili na drugi način priopćena obavijest o kaznenom djelu koje se progoni po službenoj dužnosti, upućena državnom odvjetniku izravno ili posredno ${ }^{30} \mathrm{U}$ širem smislu riječi, svaka obavijest državnom odvjetniku o tome da je počinjeno kazneno djelo predstavlja kaznenu prijavu, a u užem smislu to bi bile one prijave koje su potkrijepljene argumentima, koje sadrže priloge i podatke na temelju kojih proizlaze osnove sumnje da je počinjeno kazneno djelo. ${ }^{31}$

Sukladno čl. 204. st. 1. ZKP-a, svatko je dužan prijaviti kazneno djelo za koje se postupak pokreće po službenoj dužnosti, koje mu je dojavljeno ili za koje je saznao. Ova je odredba deklaratorne naravi, radi se o građanskoj dužnosti svake osobe čije nepoštovanje ne povlači za sobom sankcije u svakom slučaju, već samo onda kada je zakonom izrijekom propisano da takvo ponašanje predstavlja kazneno djelo. Izvan

27 I papa Benedikt XVI. jasno je isticao kako se radi o dvama pravosudnim sustavima koji mogu surađivati te je pozvao biskupe da pored potpune primjene norma crkvenoga prava u pristupu slučajevima spolnoga zlostavljanja djece surađuju s državnim tijelima na području njihove nadležnosti. Benedikt XVI., Svjetlo svijeta, 217, cit. prema Grbac, J., „Moralna i kaznena odgovornost - dodirne točke i razlike“, Riječki teološki časopis, god. 19 (2011.), br. 2, str. 266.

28 Toč. 7. Smjernica HBK.

29 Radi se o kaznenim djelima za koja progon vrši državni odvjetnik po službenoj dužnosti, u javnom interesu i neovisno o volji žrtve (čl. 38. st. 1. ZKP-a). Za većinu kaznenih djela iz Kaznenog zakona progon se vrši po službenoj dužnosti, a iznimno za pojedina kaznena djela predviđen je progon po privatnoj tužbi ili po prijedlogu žrtve. Za razliku od tih kaznenih djela, kod ex officio progona žrtva nema pravo disponirati odlukom o vršenju kaznenog progona, već je ta odluka isključivo u nadležnosti državnog odvjetnika koji progon vrši sukladno načelu legaliteta kaznenog progona (čl. 2. st. 3. ZKP-a). Opš. Krapac, D., Kazneno procesno pravo, Institucije, Zagreb, 2014., str. 89-92.

30 Tako Pavišić, B., Komentar Zakona o kaznenom postupku, drugo izdanje, Rijeka, 2013., str. 492.

31 Garačić, A.; Novosel, D., Zakon o kaznenom postupku u sudskoj praksi, knjiga prva, Rijeka, 2018. str. 511 
slučajeva predviđenih Kaznenim zakonom koji inkriminira takva ponašanja samo kada se radi o neprijavljivanju kaznenog djela za koje je propisana kazna zatvora od deset godina ili teža kazna, propust prijave kaznenog djela koje se progoni ex officio ne povlači za sobom (negativne) pravne posljedice. ${ }^{32}$

Slijedom rečenog, u slučajevima kada se pojavi sumnja da je klerik počinio kazneno djelo koje se progoni ex officio, dužnost je svake osobe, uključujući i pripadnika klera, sukladno važećem zakonodavstvu RH, prijaviti kazneno djelo državnom odvjetništvu, neovisno o obvezi prijave nadležnoj crkvenoj vlasti prema kanonskom pravu. ${ }^{33}$ Ova se dužnost ne odnosi samo na ordinarija koji predstavlja crkvenu vlast, već na svakog klerika koji ima saznanja o počinjenom kaznenom djelu neovisno o tome je li prethodno obavijestio ordinarija s ciljem daljnjeg postupanja sukladno kanonskom pravu. Ipak, logično je pretpostaviti da će kaznena prijava u pravilu ići od strane ordinarija koji može prikupiti više informacija i koji je sukladno crkvenom pravu nadležan ispitati vjerodostojnost navoda $\mathrm{i}$ inicirati prethodnu istragu. U tom smislu, Smjernice HBK-a navode obveze ordinarija povodom saznanja o počinjenju kaznenog djela spolnog zlostavljanja i iskorištavanja djeteta. Ordinarij je dužan oprezno ispitati obavijest o kažnjivome djelu te ustanoviti je li obavijest vjerodostojna. Nakon toga, shodno pozitivnim državnim propisima Republike Hrvatske, te pazeći da, sukladno kan. 1717 § 2, »ne dođe u pogibelj dobar glas bilo koga «, na prikladan način podnijeti prijavu državnim vlastima, osim ako se istraživanje čini posve suvišnim (usp. kan. 1717, § 1). ${ }^{34} \mathrm{U}$ nastavku ćemo usporediti ovako predviđene obveze crkvenim pravom s obvezama koje proizlaze iz kaznenoprocesnog zakonodavstva Republike Hrvatske.

Premda ordinarij treba ispitati vjerodostojnost obavijesti o počinjenoj kažnjivoj radnji radi odlučivanja o pokretanju i vođenju kanonskog kaznenog postupka, saznanja o počinjenom kaznenom djelu koje se progoni po službenoj dužnosti treba prijaviti državnom odvjetništvu neovisno o odluci o vođenju kanonskog kaznenog postupka. Pritom dužnost prijave kaznenog djela iz čl. 204. ZKP-a ne bi trebalo tumačiti tako da zahtijeva promptno prijaviti svako saznanje, neprovjerenu informaciju koja nije potkrijepljena barem nekim dokazima koji bi činili osnove sumnje da je počinjeno kazneno djelo. Kada je riječ o trenutku u kojem bi nastala obveza prijave, nije isto radi li se o neposrednom saznanju o počinjenom kaznenom djelu ili o posrednom saznanju, kao i jesu li osobe od kojih je ordinarij dobio takvo saznanje žrtve kaznenog djela, osobe bliske žrtvi ili netko treći, odnosno radi li se samo o glasinama koje nisu dodatno potkrijepljene. Takve glasine i saznanja potrebno je potkrijepiti dokazima posebice u slučajevima kada ordinarij kao

32 Čl. 204. st. 3. ZKP-a. O kaznenom djelu neprijavljivanja kaznenog djela opširnije infra 4.1.

33 U čl. 3. Motu proprija Vos estis lux mundi postavljena je obveza za svakog klerika te člana ustanove posvećenog života ili družbe apostolskog života obavijestiti lokalnog ordinarija mjesta gdje su se inkriminirani događaji zbili o saznanjima ili utemeljenim razlozima za vjerovanje da je počinjena jedna od kažnjivih radnji navedenih u čl. 1. st. 1.a.) Motu proprija (a koje ujedno predstavljaju kaznena djela sukladno KZRH-a). Motu proprij sankcionira također djelovanja i propuštanja usmjerena na ometanje ili izbjegavanje ne samo kanonskih već i civilnih istraga (istraga državnih tijela) protiv klerika ili redovničkih osoba za predmetne delikte.

34 Toč. 7. Smjernica HBK-a. 
nadležna odgovorna osoba u pravnoj osobi prijavljuje kazneno djelo za koje je saznao u obavljanju svojih poslova ili koje je počinjeno na štetu te pravne osobe, a u skladu s čl. 204. stavkom 2. ZKP-a. ${ }^{35}$

S druge strane, rečeno ne daje placet odugovlačenju s podnošenjem kaznene prijave jer je u konačnici državno odvjetništvo tijelo nadležno utvrditi je li kaznena prijava vjerodostojna odnosno proizlazi li iz prijave osnovana sumnja dostatna za pokretanje istrage (ili istraživanja), ili je prethodno potrebno provesti izvide kaznenih djela. ${ }^{36}$ Stoga ordinarij ne bi smio a priori vezivati trenutak podnošenja prijave kaznenog djela državnom odvjetništvu uz odluku o pokretanju prethodne istrage ili pak uz njezin ishod. Prethodna istraga jest stadij prije početka kanonskog kaznenog postupka upravnog karaktera koji smjera utvrđivanju istinitosti obavijesti o deliktu koji bi mogao predstavljati kažnjivu radnju. ${ }^{37}$ Već sama prethodna (kanonska) istraga pretpostavlja određenu čvrstoću pokazatelja protiv neke osobe tj. objektivni i subjektivni element kažnjivog djela. ${ }^{38}$ Premda se u prethodnoj istrazi ispituje utemeljenost obavijesti o počinjenom kažnjivom djelu, to je tek jedan od uvjeta za provođenje prethodne istrage. Moguće je tako da ordinarij utvrdi kako nije ispunjen neki od uvjeta za provođenje prethodne istrage ${ }^{39}$ unatoč tome što postoji sumnja da je počinjeno kažnjivo djelo koje je ujedno i kazneno djelo koje se progoni ex officio prema KZRH-u i koje je stoga potrebno prijaviti nadležnim državnim tijelima. U određenim slučajevima provođenje prethodne istrage može biti suvišno jer je kažnjivo djelo potpuno sigurno utvrđeno, ${ }^{40}$ što također podrazumijeva dužnost podnošenja prijave državnom odvjetništvu. Osim toga, ordinarij može po okončanju prethodne istrage odlučiti da se, premda postoji mogućnost pokretanja kanonskog kaznenog postupka, postupak ipak ne provede jer to ne bi bilo primjereno s obzirom na zahtjeve milosrđa, blagosti, a imajući u vidu činjenicu da izricanje kanonskih kazni predstavlja krajnje sredstvo. ${ }^{41}$ Međutim, čak i ako zaključi da s aspekta kanonske pravičnosti nema potrebe za vođenjem kanonskog kaznenog postupka,

35 Usp. Garačić, A.; Novosel, D., op. cit. u bilj. 31, str. 512. Čl. 204. st. 2. ZKP-a predviđa da podnoseći prijavu, tijela državne vlasti i pravne osobe trebaju navesti dokaze koji su im poznati i poduzeti sve da bi se sačuvali tragovi kaznenog djela, predmeti na kojima je ili kojima je počinjeno djelo te drugi dokazi.

36 Sukladno čl. 206. st. 4. i 5., ako državni odvjetnik iz prijave ne može ocijeniti jesu li vjerodostojni navodi prijave ili ako podaci u prijavi ne daju dovoljno osnove da može odlučiti hoće li provesti istragu ili poduzeti dokazne radnje, državni odvjetnik će sam provesti izvide ili naložiti njihovo provođenje policiji. Ako i nakon poduzetih izvida nije utvrđena osnovana sumnja ili podaci ukazuju da prijava nije vjerodostojna ili postoje druge okolnosti iz čl 206. st. 1. ZKP-a, državni će odvjetnik odbaciti prijavu.

37 Astigueta, D. G., „L'investigazione previa: alcune problematiche“, Periodica de Re Canonica, Vol. 98, No 2, 2009., Pontificia Università Gregoriana Roma, str. 199.

38 Svažić, E., „Kažnjiva djela, kaznene mjere i kazneni postupak u Crkvi“, Riječki teološki časopis, god. 19 (2011.), br. 2, str. 346.

39 Tri su preduvjeta za provođenje prethodne istrage po kanonskom pravu: utvrđivanje mjerodavnosti, razmatranje stupnja utemeljenosti obavijesti o počinjenom kažnjivom djelu te donošenje odluke o pokretanju prethodne istrage. Tako Šalković, J., „Prethodna istraga u kaznenom postupku“, Posebni sudski postupci i postupanja, Zbornik radova Međunarodnog znanstvenog simpozija crkvenih pravnika u Lovranu, 26.-27. X. 2009., Zagreb, 2010., str. 241-243.

40 Opš. Šalković, J., op. cit. u bilj. 39, str. 242.

41 Vidi ibidem, str. 249. 
ordinarij je dužan podnijeti kaznenu prijavu državnom odvjetništvu ako dokazi upućuju na to da je počinjeno kazneno djelo koje se progoni ex officio.

Odlaganje s prijavljivanjem kaznenog djela u navedenim situacijama otežava otkrivanje i kažnjavanje počinitelja kaznenih djela te može dovesti do nastupa zastare kaznenog progona, ${ }^{42}$ a isključivo je državni odvjetnik tijelo ovlašteno utvrditi jesu li ispunjene (pozitivne i negativne) pretpostavke za vršenje kaznenog progona. Stoga je na crkvenim vlastima da adekvatno i pravodobno reagiraju na saznanja o počinjenom kaznenom djelu od strane klerika, da prikupe dokaze i ispitaju vjerodostojnost prijave za potrebe kanonskog postupka, ali istovremeno da prijave svoja saznanja državnom odvjetništvu kako bi se osigurao učinkovit progon i kažnjavanje počinitelja kaznenih djela, pogotovo težih kaznenih djela čije neprijavljivanje može biti i samo sankcionirano sukladno Kaznenom zakonu.

\subsection{Obavještavanje crkvenih vlasti o istrazi protiv klerika}

Drugi aspekt suradnje države i Crkve u kaznenim postupcima odnosi se na obvezu obavještavanja crkvenih vlasti o istrazi protiv klerika. Naime, sukladno članku 8. Ugovora o pravnim pitanjima ,u slučaju sudske istrage o kleriku zbog možebitnih krivičnih djela predviđenih krivičnim zakonikom, sudske vlasti će o tome prethodno obavijestiti nadležne crkvene vlasti." Prije nego što analiziramo navedenu odredbu u kontekstu našeg pravnog sustava, treba reći da odredbu sličnog sadržaja sadrže i ugovori Svete Stolice s nekim drugim europskim državama (s Austrijom, ${ }^{43}$ Italijom, ${ }^{44}$ Španjolskom ${ }^{45}$ ). Ratio obveze obavještavanja o provođenju istrage jest u omogućavanju crkvenim vlastima da pravodobno reagiraju u odnosu na klerika koji je okrivljen za određeno kazneno djelo te da osiguraju neometano obavljanje pastoralne djelatnosti. ${ }^{46}$ Drugi razlog propisivanju ove obveze jest

42 Zastara kaznenog progona predstavlja negativnu procesnu pretpostavku i razlog je za odbačaj kaznene prijave.

43 Konkordat s Republikom Austrijom sadrži detaljniju odredbu u čl. XX. prema kojoj je građanski sud dužan u slučaju kaznene prijave obavijestiti nadležne vlasti o rezultatima istrage te kada je to slučaj i o pravorijeku u prvom stupnju i u prizivu. Vidi Eterović, N.: Ugovori između Svete Stolice i Republike Hrvatske, povijest nastanka i komentar, Zagreb, 2001., str. 166-167.

44 Dodatni protokol Ugovoru između Svete Stolice i Republike Italije od 18. II. 1984. sadrži odredbu prema kojoj su sudska tijela dužna obavijestiti nadležne crkvene vlasti o provođenju kaznenog postupka protiv klerika. Odredbe o obavještavanju razrađene su u čl. 129. Pravila o provedbi Zakona o kaznenom postupku (Norme di attuazione, di coordinamento e transitorie del codice di procedura penale). Kako se tumači, ova obveza nastaje u trenutku podizanja optužbe jer fluidan karakter prethodnih istraživanja ne opravdava službenu komunikaciju s tijelom u kojem je osumnjičenik zaposlen. Jedina iznimka postoji u slučajevima uhićenja ili pritvora kada se smatra da te mjere ograničenja prava i odluka o njima opravdavaju prethodno obavještavanje. Gaito, A. (ur.), Codice di procedura penale, Commentato, Utet Giuridica, 2012., str. 4467. Neki autori ističu kako je odredba Dodatnog protokola u suprotnosti s načelom tajnosti prethodnih istraživanja odnosno tajnosti upisa osumnjičenika u upisnik kaznenih prijava. Barbagallo, R.; Pino, M., Diritto ecclesiastico, Key editore, Milano, 2019., str. 115.

45 U slučaju sudske istrage o kleriku ili redovniku nadležna će vlast o tome obavijestiti mjerodavnog ordinarija. URL=https://www.iuscangreg.it/conc/spagna-1976.pdf.

46 Usp. Eterović, N., op. cit. u bilj. 45, str. 166. Smjernice HBK-a naglašavaju kako je obavještavanje tijela kaznenog postupka mjerodavnoj crkvenoj vlasti o pokretanju kaznene istrage protiv klerika važno s obzirom na to da na temelju takve obavijesti crkvena tijela mogu u određenim okolnostima pokrenuti prethodnu istragu na crkvenome području (toč. 8.). 
mogućnost pružanja potpore okrivljenom kleriku u vidu angažiranja branitelja te pružanja psihološke potpore. ${ }^{47}$

Ono što se problematizira u našoj pravnoj teoriji te u javnom političkom životu u odnosu na čl. 8. jest formulacija odredbe iz koje proizlazi da bi crkvene vlasti trebale biti obaviještene već o samoj namjeri provođenja istrage, dakle prije nego što je istraga započeta. Time se, kako se navodi, daje kvaziimunitet pripadnicima klera, privilegira ih se u odnosu na druge građane i omogućava upletanje crkvenih vlasti u sudske postupke prije nego li oni uopće započnu, što bi predstavljalo kršenje načela odvojenosti Crkve i države, ustavno načelo jednakosti sviju pred zakonom. ${ }^{48}$

Prije nego raspravimo ovo pitanje, potrebno je prethodno ukazati na izmjene kaznenoprocesnog zakonodavstva do kojih je došlo nakon sklapanja Ugovora o pravnim pitanjima, a koje utječu i na pitanje koje tijelo i kada bi trebalo obavijestiti crkvene vlasti o istrazi protiv klerika sukladno ovoj odredbi. Velikom reformom kaznenog postupka 2008. godine ukinuta je stoljetna tradicija mješovitog tipa kaznenog postupka te je sudska istraga (koju spominje čl. 8. Ugovora) zamijenjena modelom državnooodvjetničke istrage. ${ }^{49}$ Istragu kao formalni stadij kaznenog postupka pokreće rješenjem o istrazi i vodi državni odvjetnik koji u istrazi prikuplja dokaze protiv okrivljenika. S obzirom na to da istraga više nije sudska i ne vodi je istražni sudac, u kontekstu važećeg zakonodavstva može se zaključiti da bi dužnost obavještavanja nadležnih crkvenih vlasti o provođenju istrage bila na državnom odvjetništvu. ${ }^{50}$

Obveza obavještavanja crkvenih vlasti o provođenju istrage, nakon što je istraga pokrenuta ne bi trebala biti sporna niti s ustavnopravnog aspekta niti s aspekta (ostvarivanja) učinkovitosti kaznenog postupka. Naime, pravomoćnošću rješenja o provođenju istrage započinje formalno kazneni postupak. Istraga je nejavna što znači da radnjama koje se poduzimaju tijekom istrage osobe koje nisu sudionici u postupku nemaju pravo biti nazočne, ali je dopušteno sudionicima dokaznih radnji iznositi informacije koje su saznali sudjelovanjem u dokaznoj radnji. Stoga činjenica da bi crkvene vlasti bile formalno obaviještene o tome da se istraga provodi protiv pripadnika klera ne ugrožava tijek $\mathrm{i}$ ishod istrage niti predstavlja

47 Usp. Barbagallo, R.; Pino, M., op. cit. u bilj. 44, str. 115.

48 Staničić, F., ,Treba li nam revizija ugovora sa Svetom Stolicom?“, Zbornik PFZ, 68, (3-4), 2018, str. 417

49 Opš. Đurđević, Z., „Suvremeni razvoj hrvatskoga kaznenog procesnog prava s posebnim osvrtom na novelu ZKP iz 2011.“, Hrvatski ljetopis za kazneno pravo i praksu (Zagreb), vol. 18, broj 2/2011, str. 311. Za detaljno objašnjenje razloga reformi vidjeti Pavišić, B., „Novi hrvatski Zakon o kaznenom postupku“, Hrvatski ljetopis za kazneno pravo i praksu (Zagreb), vol. 15, broj 2/2008, str. 489-602.

50 Međutim, istraga nije uvijek obvezna, postoje kaznena djela za koja se istraga neće ili ne mora provesti. U prvu kategoriju spadaju lakša kaznena djela za koja je zapriječena novčana kazna ili kazna zatvora do pet godina a za koja se ne provodi istraga već istraživanje (čl. 213. ZKP-a). Istraživanje, sukladno ZKP-u, predstavlja skup procesnih radnji koje državni odvjetnik poduzima kada postoji osnovana sumnja da je osumnjičenik počinio kazneno djelo. Za razliku od istrage, državni odvjetnik ne donosi formalnu odluku o započinjanju istraživanja, te u ovim slučajevima kazneni postupak ne započinje provođenjem istraživanja već sudskim potvrđivanjem optužnice. Opš. o istraživanju kod Carić, M., „Istraživanje - zakonodavni okvir i praktična primjena“, Hrvatski ljetopis za kaznene znanosti i praksu (Zagreb), vol. 25., broj 2/2018., str. 520-524. 
posebnu povlasticu za okrivljene klerike. Tim više što Ugovor o pravnim pitanjima ne zahtijeva obavještavanje o sadržaju istrage tj. o sadržaju pojedinih dokaznih radnji već isključivo o činjenici provođenja istrage. ${ }^{51} \mathrm{U}$ tom smislu, i ugovori između Vlade RH i drugih vjerskih zajednica (primjerice islamske zajednice, Srpske pravoslavne crkve itd.) sadrže odredbu o obavještavanju nadležnog crkvenog tijela o pokrenutom kaznenom postupku protiv vjerskog službenika za kaznena djela koja se progone po službenoj dužnosti.

Ono što je sporno u odredbi čl. 8. stavka 2. jest da bi nadležno tijelo bilo dužno obavijestiti crkvene vlasti već o namjeri provođenja istrage protiv pripadnika klera, dakle prije nego što donese rješenje o istrazi što može insinuirati mogućnost interveniranja u postupak koji još formalno nije započeo. Istrazi prethode izvidi kaznenih djela koji su, sukladno ZKP-u, tajni. Radi se o pretkaznenom postupanju odnosno radnjama koje se poduzimaju da bi se osnove sumnje pretvorile $u$ osnovanu sumnju, čiji se rezultati u pravilu ne mogu koristiti kao dokaz u postupku. Obavještavanje drugih osoba o provođenju izvida može dovesti u pitanje uspješnost i učinkovitost poduzetih radnji kao i daljnji tijek postupka pa je s tog aspekta dvojbena opravdanost obavještavanja crkvenih vlasti kao i bilo koje druge osobe odnosno tijela koje ne sudjeluje u izvidima o tijeku izvida kaznenih djela. Međutim, prethodno obavještavanje o istrazi o kojem govori čl. 8. st. 2. podrazumijevalo bi da je državni odvjetnik već utvrdio da su ispunjene pretpostavke za pokretanje istrage odnosno da ju je odlučio pokrenuti pa bi gramatičko tumačenje ove odredbe značilo obavještavanje crkvenih vlasti nakon što su izvidi dovršeni a neposredno prije donošenja rješenja o provođenju istrage. Valja primijetiti da se Komentar Ugovora o pravnim pitanjima ne referira na obvezu prethodnog obavještavanja (prije nego je istraga započeta) već proizlazi kako je riječ o obvezi obavještavanja o vođenju kaznenog postupka tj. istrage, a ne u davanju neke posebne povlastice kleriku prije nego što je postupak započeo..$^{52}$ Ovdje treba dodati i da Zakon o kaznenom postupku predviđa u određenim slučajevima mogućnost obavještavanja određenih tijela i ustanova u kojima su zaposleni osumnjičenici i okrivljenici o pokretanju istrage, ali i o određivanju pojedinih mjera procesne prisile koje prethode istrazi. ${ }^{53}$

Što se pak tiče provedbe odredbe čl. 8. st. 1. Ugovora o pravnim pitanjima u praksi, iz obavijesti dobivene od Državnog odvjetništva Republike Hrvatske

51 Za razliku od odredbe $\mathrm{u}$ konkordatu s Austrijom, člankom 8. Ugovora predviđa se samo dostavljanje obavijesti mjerodavnim crkvenim vlastima o istrazi klerika, a ne i dostavljanje rezultata istrage ili pravorijeka. Smjernice HBK-a obrazlažu da, ako je u pitanju klerik, sudske vlasti dužne su obavijestiti o istrazi dijecezanskoga biskupa, ako se radi o kleriku redovniku obavijestit će više redovničke poglavare kleričkih ustanova papinskoga prava te više poglavare kleričkih družbi apostolskoga života papinskoga prava, ako se radi o kleriku članu tih družbi. Ako bi se pak radilo o biskupima, sudbene vlasti morale bi obavijestiti Svetu Stolicu, i to redovito preko Apostolske nuncijature.

52 Vidjeti Eterović, N., op. cit. u bilj. 43, str. 166.

53 Prema čl. 198. ZKP-a o pokretanju istrage protiv vojnih osoba, te protiv državnih službenika i namještenika na službi u oružanim snagama Republike Hrvatske ili u policiji, kao i o određivanju pritvora, istražnog zatvora u domu i istražnog zatvora, državni odvjetnik dužan je o tome obavijestiti nadležno ministarstvo. Također obavijest o određivanju pritvora, istražnog zatvora u domu i istražnog zatvora protiv državnog službenika ili namještenika dostavit će se rukovoditelju tijela ili ustanove prema posebnom propisu. 
proizlazi da ovo tijelo ne obavještava crkvene vlasti o provođenju istrage odnosno o poduzimanju bilo kakvih radnji protiv klerika. ${ }^{54}$ Kad je riječ o obavještavanju, državno odvjetništvo postupa sukladno čl. 206. st. 3. te čl. 206.c. st. 2. i čl. 206.d. st. 3. i 4. ZKP-a kada donosi rješenje o odbačaju kaznene prijave i čl. 218. st. 7. ZKP-a kada donosi rješenje o provođenju istrage. ${ }^{55}$ To znači da će crkvene vlasti biti obaviještene o poduzetim radnjama državnog odvjetništva isključivo u onim slučajevima kada se nalaze u svojstvu podnositelja kaznene prijave ili pak u svojstvu žrtve te oštećenika.

Međutim, suprotno obrazloženju DORH-a, a kako je prethodno spomenuto, važeći Zakon o kaznenom postupku ipak sadrži odredbu o obavještavanju tijela iz čijih redova dolaze osumnjičenici odnosno okrivljenici. Premda Zakon o kaznenom postupku ne propisuje izrijekom takvu obvezu u odnosu na obavještavanje crkvenih vlasti o istrazi protiv klerika, ta je obveza postavljena Ugovorom o pravnim pitanjima koji je po svojoj pravnoj snazi iznad zakona pa nije nužno da ista bude propisana ZKP-om. Ipak, radi lakše i učinkovitije provedbe, bilo bi svrhovito da je sadržana u kaznenoprocesnom zakonodavstvu, pogotovo s obzirom na probleme koje proizlaze iz odredbe čl. 8. o trenutku obavještavanja; razrada ove obveze na način kako je to već predviđeno u stavku 3. članka 198. ZKP-a u odnosu na vojne osobe, pomogla bi razrješavanju nedoumica odnosno ublažila nes(p)retnu formulaciju iz stavka 2. čl. 8. Ugovora.

\subsection{Sudjelovanje klerika u kaznenom postupku u svojstvu svjedoka}

Pripadnik klera može sudjelovati u kaznenom postupku u različitim svojstvima: u svojstvu okrivljenika, oštećenika, svjedoka, i u takvim slučajevima ima sva prava i obveze koje sukladno ZKP-u pripadaju sudionicima kaznenog postupka. Prethodno je bilo riječi o podnošenju kaznene prijave te smo ustvrdili da se odredbe ZKP-a bez iznimke odnose i na pripadnike klera i na crkvena tijela u svojstvu prijavitelja. Zatim je analizirana obveza obavještavanja koja proizlazi iz čl. 8. st. 2. Ugovora o pravnim pitanjima u slučajevima kada se klerik pojavi u svojstvu osumnjičenika ili okrivljenika. Potrebno je naglasiti da, uz činjenicu obavještavanja crkvenih vlasti o istrazi protiv klerika, status klerika ni na koji način ne utječe na prava i obveze koje ta osoba ima kao okrivljenik u kaznenom postupku sukladno Zakonu o kaznenom postupku. ${ }^{56}$ To znači da uživa sva prava zajamčena Zakonom o kaznenom postupku bez razlike u odnosu na druge osobe koje se nalaze u svojstvu osumnjičenika i okrivljenika, ali isto tako da se ne može izuzeti od dužnosti inherentnih njegovu pravnom položaju (podvrgavanje mjerama procesne prisile, korištenje kao pasivnog

54 U obrazloženju se navodi kako važećim procesnim odredbama nije propisana obveza državnog odvjetništva da o poduzimanju radnji sukladno odredbama ZKP/08 protiv počinitelja kaznenih djela prethodno ili o tome obavještava tijela i/ili institucije iz čijih redova dolaze počinitelji kaznenih djela. Državno odvjetništvo Republike Hrvatske, dopis A-623/2019 od 7. studenog 2019. godine.

55 Iz ovih odredaba proizlazi obveza obavještavanja žrtve te podnositelja kaznene prijave o odbačaju kaznene prijave te obavještavanja oštećenika o donošenju rješenja o provođenju istrage.

56 Prava okrivljenika nabrojana su u čl. 64. ZKP-a. 
dokaznog sredstva).$^{57} \mathrm{U}$ slučajevima kada je klerik, ili pak crkveno tijelo kao pravna osoba oštećeno kaznenim djelom, pripadaju mu sva prava koja ZKP pruža oštećeniku u kaznenom postupku. ${ }^{58}$

Zakonodavac ipak prepoznaje specifičan položaj vjerskog ispovjednika u odnosu na dužnost svjedočenja. Opća dužnost svjedočenja obuhvaća dužnost pojaviti se pred sudom, dati svoj iskaz i iskazivati istinito, ${ }^{59}$ ali od te opće dužnosti predviđene su i određene iznimke. Takvu iznimku zakonodavac, inter alia, propisuje u odnosu na vjerskog ispovjednika koji se ne može ispitati kao svjedok u odnosu na sadržaj ispovjedne tajne ${ }^{60}$ Radi se o jednoj od iznimki predviđenih u čl. 284. ZKP-a koje imaju za cilj očuvanje drugog društvenog interesa koji je jači od vođenja kaznenog postupka ${ }^{61}$ Međutim, za razliku od nekih drugih kategorija osoba obuhvaćenih ovom odredbom koje u određenim okolnostima ipak mogu svjedočiti, ${ }^{62}$ dakle imaju relativnu nesposobnost za svjedočenje, vjerskog ispovjednika nije moguće ni u kojem slučaju osloboditi čuvanja sakramentalnog pečata pa se može govoriti o apsolutnoj nesposobnosti za svjedočenje. ${ }^{63}$ Izvan ovog slučaja, klerik može biti oslobođen obveze svjedočenja u kaznenom postupku ili može odbiti odgovoriti na pojedina pitanja samo ako postoje druge okolnosti propisane ZKP-om nevezane uz svojstvo vjerskog ispovjednika a koje djelomično ili u cijelosti oslobađaju osobu od dužnosti iskazivanja. ${ }^{64}$ Za razliku od kategorije svjedoka koji su oslobođeni dužnosti svjedočenja (čl. 285. ZKP-a) i koji samostalno odlučuju hoće li svjedočiti ili ne, osobe koje se ne mogu ispitati kao svjedoci, među kojima je vjerski ispovjednik, ${ }^{65}$ nisu samo oslobođene dužnosti svjedočenja već je svjedočenje isključeno, dakle, niti takav svjedok smije svjedočiti niti ga tijelo kaznenog postupka smije ispitivati, osim ako sam zakon ne dopušta drugačije. ${ }^{66}$ To znači, ako bi vjerski ispovjednik odlučio iskazivati odnosno iznijeti sadržaj ispovijedi, njegov iskaz ne bi se ni u

57 Krapac, D., op. cit. u bilj. 29, str. 234-235.

58 Prava oštećenika navedena su u čl. 51. ZKP-a, prava žrtve: čl. 43. ZKP-a.

59 Krapac, D., op. cit. u bilj. 29, str. 487-488.

60 Ova iznimka uključuje vjerske ispovjednike generalno, nije ograničena na vjerske ispovjednike u okviru Katoličke crkve za koje je nepovredivost ispovjedne tajne zajamčena Ugovorom o pravnim pitanjima. $\mathrm{O}$ ispovjednoj tajni i pravnim temeljima nepovredivosti ispovjedne tajne opširnije infra 4.3.1.

${ }^{61}$ Krapac, D., op. cit. u bilj. 29, str. 488.

62 Tako osoba koja bi svojim iskazom povrijedila zakonom ustanovljenu obvezu čuvanja tajnosti podataka može dati svoj iskaz ako je nadležno tijelo oslobodi te obveze (čl. 284. t. 1.), a branitelj okrivljenika može svjedočiti ako to sam okrivljenik zahtijeva (čl. 284. t. 2.).

${ }_{63}$ Usp. Mrčela, M., Svjedoci u kaznenom postupku, Ispitivanje svjedoka kao dokazna radnja, Narodne novine, Zagreb, 2012., str. 29.

64 Tako zakonodavac daje povlasticu da ne moraju svjedočiti osobe koje su s okrivljenikom u bliskoj vezi određenoj zakonom (čl. 285. ZKP-a) što znači da klerik može odbiti svjedočiti u postupku koji se vodi protiv njegova rođaka u ravnoj lozi ili u pobočnoj zaključno do trećeg stupnja. Osim toga, povlasticu da ne moraju odgovoriti na pojedina pitanja imaju osobe koje bi time izložile sebe ili svog bliskog srodnika kaznenom progonu, teškoj sramoti ili znatnoj materijalnoj šteti (čl. 286. st. 1.) što podrazumijeva da i klerik može u rečenim okolnostima iskoristiti ovu povlasticu.

65 Prije donošenja prvog hrvatskog Zakona o kaznenom postupku iz 1997. godine, vjerski ispovjednik je u odnosu na sadržaj ispovijedi, sukladno čl. 217. Zakona o krivičnom postupku koji je Republika Hrvatska preuzela nakon osamostaljenja, spadao pod kategoriju osoba koje su oslobođene dužnosti svjedočenja.

66 Usp. Vasiljević, T., Sistem krivičnog procesnog prava SFRJ, Beograd, 1981., str. 357-359. 
kojem slučaju mogao upotrijebiti kao dokaz u kaznenom postupku. ${ }^{67}$ Međutim, pripadnik klera u svakom je slučaju dužan odazvati se na poziv suda i ako ne postoje okolnosti iz čl. 284. ili 285. ZKP-a, dati svoj iskaz.

\section{KAZNENOPRAVNE POSLJEDICE NEPRIJAVLJIVANJA KAZNENOG DJELA I ISPOVJEDNA TAJNA}

Prethodno je u radu analizirana obveza prijavljivanja počinjenog kaznenog djela za koje se progoni po službenoj dužnosti a koja proizlazi iz čl. 204. ZKP-a. Ova pozitivna obveza građana te svih tijela državne vlasti i pravnih osoba, pa time i klerika, može se razmatrati kroz pojedina kaznena djela u Kaznenom zakonu. Stoga će se u ovom dijelu rada analizirati kaznena djela postdeliktnog pomaganja kao što su neprijavljivanje počinjenog kaznenog djela i pomoć počinitelju nakon počinjenog kaznenog djela. $\mathrm{S}$ obzirom na to da je vjerski ispovjednik vezan ispovjednom tajnom, postavlja se pitanje je li u određenim slučajevima ipak dopušteno otkriti ispovjednu tajnu, za što je potrebno analizirati pravne propise koji reguliraju pravni položaj vjerskog ispovjednika u odnosu na isključenje protupravnosti kod kaznenog djela neovlaštenog otkrivanja profesionalne tajne.

\subsection{Neprijavljivanje počinjenog kaznenog djela (čl. 302. KZ-a)}

Da bi klerik bio kažnjen za neprijavljivanje počinjenog kaznenog djela, potrebno je da se ostvari zakonski opis kaznenog djela neprijavljivanja počinjenog kaznenog djela iz čl. 302. KZ-a. Ovdje je bitno da se radi o kaznenom djelu za koje je propisana kazna zatvora od deset godina ili teža kazna. ${ }^{68}$ Za razliku od čl. 300. st. 1. Kaznenog zakona iz 1997.. ${ }^{69}$ prema važećoj odredbi čl. 302. st.1. KZ-a, odgovornost za neprijavljivanje postojat će i ako se radi o osjetno lakšem kaznenom djelu, tj. onom za koje je propisana kazna zatvora od deset godina ili teža kazna. Za ostvarenje zakonskog opisa bitno je da se ispuni i drugi uvjet, odnosno da klerik ne prijavi kazneno djelo, iako zna da bi takvom prijavom bilo omogućeno ili znatno olakšano otkrivanje djela ili počinitelja. Namjera počinitelja je dvojaka. Ona mora obuhvatiti svijest o težini počinjenog kaznenog djela i svijest da bi prijavljivanje omogućilo ili znatno olakšalo otkrivanje djela ili počinitelja. Kao oblik krivnje dovoljna je i neizravna namjera. Proširivanje kaznene odgovornosti i na onoga tko bi morao znati (normativni element nehaja) značilo bi nedopuštenu analogiju. ${ }^{70}$ Svijest počinitelja

67 Čl. 300. ZKP-a. Riječ je o nezakonitom dokazu pa bi korištenje takvog iskaza u postupku predstavljalo bitnu povredu odredaba kaznenog postupka (čl. 468. st. 2. ZKP-a).

68 Derenčinović, D. u Cvitanović, L., Derenčinović, D., Turković, K., Munivrana Vajda, M., Dragičević Prtenjača, M., Maršavelski, A., Roksandić Vidlička, S., Kazneno pravo - Posebni dio, Zagreb, 2018., str. 433.

69 Prema KZ97 bilo je kažnjivo isključivo neprijavljivanje kaznenog djela za koje je propisana kazna dugotrajnog zatvora (čl. 300. st. 1. KZ97).

70 Derenčinović, D. u Novoselec, P. (ur.), Posebni dio kaznenog prava, Zagreb, 2007., str. 348. 
mora obuhvatiti faktične okolnosti koje djelo čine teškim, no ne mora znati sve detalje iz bića kaznenog djela kao ni propisanu kaznu. Nebitno je na koji način se i kako saznalo za djelo i počinitelja. ${ }^{71}$ Neprijavljivanje počinjenog kaznenog djela jedna je vrsta pomaganja počinitelju nakon počinjenog kaznenog djela ${ }^{72}$ Razlika je što namjera kod pomaganja nakon počinjenja kaznenog djela mora obuhvatiti i svijest da se pomaže počinitelju kaznenog djela, što nije obilježje bića kaznenog djela neprijavljivanja počinjenog kaznenog djela. Počinitelj može biti svaka osoba (delictum communium). Ovdje bi se radilo o pravom kaznenom djelu nečinjenja koje se iscrpljuje u radnji i kod kojeg je posljedica izvan bića kaznenog djela. Kazneno je djelo ostvareno u onom trenutku kad je kod počinitelja postojala obveza na činjenje, a to je u trenutku saznanja za ostvarenje kaznenog djela. ${ }^{73}$ Neće se kazniti za neprijavljivanje onaj tko je na drugi način spriječio počinjenje kaznenog djela. ${ }^{74}$ Eventualna posljedica (okolnost da počinitelj zbog propuštanja pravovremene prijave počini novo kazneno djelo) ne utječe na postojanje kvalifikacije ovog djela, ali je sud može uzeti u obzir kao otegotnu okolnost kod odmjeravanja kazne. ${ }^{75}$

Otkrivanje počinitelja znači otkrivanje njegove istovjetnosti, ali i otkrivanje skloništa počinitelja koji je poznat. ${ }^{76}$ Potrebno je prijaviti da je kazneno djelo počinjeno, a ako je osobi poznat i počinitelj, tada je dužna i tu činjenicu navesti, odnosno, otkrivanje njegove istovjetnosti ali i otkrivanje skloništa počinitelja koji je poznat. ${ }^{77}$ Ako netko prijavi počinjenje kaznenog djela i kao počinitelja navede osobu za koju zna da nije počinila to kazneno djelo, radit će se o kaznenom djelu lažnog prijavljivanja te prijavitelj mora voditi računa o vjerodostojnosti svoje prijave. Pravovremenost otkrivanja postoji ako se sprečava da kazneni postupak bude pokrenut ili kada kazneni postupak ne može započeti ili biti dovršen. Krivnja će otpasti ako netko tko zna za počinjenje djela to ne prijavi jer pogrešno drži da je nadležno tijelo o tome već izviješteno (nedostaje svijest o tome da o prijavi djela ovisi otkrivanje djela i počinitelja). ${ }^{78}$

U stavku 2. propisano je da službene i odgovorne osobe odgovaraju za neprijavljivanje bilo kojeg počinjenog kaznenog djela koje se progoni po službenoj dužnosti, a ne samo za neprijavljivanje teškog kaznenog djela za koje je propisana kazna zatvora od deset godina ili teža. Sukladno čl. 87. st. odgovorna je ona fizička osoba koja vodi poslove pravne osobe ili joj je izričito ili stvarno povjereno obavljanje poslova iz područja djelovanja pravne osobe ili državnih tijela ili tijela jedinice lokalne i područne (regionalne) samouprave. Stoga bi odgovorna osoba u kanonskom pravu bio ordinarij. Uvjet je za ostvarenje st. 2. da je počinitelj

71 Pavlović, Š., Kazneni zakon, Rijeka, 2012., str. 651.

72 O odnosu između ova dva kaznena djela opširnije infra 4.2.

73 Garačić, A., Kazneni zakon u sudskoj praksi, Posebni dio, Zagreb, 2009., str. 672.

74 Pavlović, Š., op. cit. u bilj. 71., str. 651; Bačić, F., Pavlović, Š.: Komentar Kaznenog zakona, Zagreb, 2004., str. 1047.

75 Derenčinović, D. u Novoselec, P. (ur.), op. cit. u bilj. 70, str. 348.

76 Derenčinović, D. u Cvitanović et al., op. cit. u bilj. 68, str. 433.

77 Derenčinović, D. u Novoselec, P. (ur.), op. cit. u bilj. 70, str. 348.

78 Pavlović, Š., op. cit. u bilj. 71, str. 651. 
saznao za počinjeno kazneno djelo obavljajući svoju dužnost. To znači da ako je za počinjenje kaznenog djela saznao izvan obavljanja svoje dužnosti, neće odgovarati za kvalificirani oblik kaznenog djela, ${ }^{79}$ ali bi, ako su ispunjeni svi ostali uvjeti, bio odgovoran za temeljni oblik kaznenog djela. Vrsta i mjera kazne za st. 2. određena je kao nekažnjavanje strožom kaznom od one koja je propisana za kazneno djelo koje službena ili odgovorna osoba nije prijavila. Isključena je protupravnost djela, primjerice, ako bi se na strani osobe koja je propustila prijavu radilo o krajnjoj nuždi ${ }^{80}$ primjenom odredbi Općeg dijela Kaznenog zakona. Od dužnosti prijavljivanja kaznenog djela, pa i kaznenog djela počinjenog prema djetetu, zakon izričito izuzima i vjerskog ispovjednika ili osobu koja je prema zakonu dužna čuvati tajnu. Međutim, za primijetiti je da zakonodavac nije na isti način predvidio izuzeće za vjerskog ispovjednika i osobu koja je prema zakonu dužna čuvati tajnu i kod kaznenog djela Neprijavljivanja pripremanja kaznenog djela iz čl. 301. KZ-a. ${ }^{81}$ Premda se nepostojanje obveze prijavljivanja pripremanja kaznenog djela za ove kategorije osoba može izvesti iz čl. 145. KZ-a koji regulira neovlašteno otkrivanje profesionalne tajne, ${ }^{82}$ postavlja se pitanje opravdanosti i logike zakonodavnog rješenja prema kojem su vjerski ispovjednik i osoba koja je dužna čuvati tajnu izričito spomenuti u čl. 302. KZ-a, a nisu navedeni i u čl. 301. KZ-a.

\subsection{Pomoć počinitelju nakon počinjenja kaznenog djela (čl. 303. KZ-a)}

Kazneno djelo pomoći počinitelju nakon počinjenja kaznenog djela podrazumijeva dvije vrste kažnjivih radnji, one kojima se počinitelju kaznenog djela pomaže da ne bude otkriven i one kojima se ide za tim da se ne izvrši izrečena kazna zatvora. Za postojanje ovog kaznenog djela nije bitno je li radnja počinjenja bila uspješna. Jedne $i$ druge radnje znače ometanje rada pravosudnih tijela u njihovoj društvenoj funkciji suzbijanja kriminaliteta, u njihovu neometanom obavljanju obveza i ovlaštenja hvatanja i kažnjavanja počinitelja kaznenih djela. ${ }^{83}$ Temeljni oblik ovog kaznenog djela ima pet načina koji se sastoje u prikrivanju ili zbrinjavanju počinitelja kaznenog djela, prikrivanju sredstava kojima je kazneno djelo počinjeno, prikrivanje tragova kaznenog djela, prikrivanje predmeta nastalih ili pribavljenih kaznenim djelom, svaki drugi oblik pomaganja da počinitelj ne bude otkriven ili uhićen (generalna klauzula, npr. upućivanje istrage tijela kaznenog progona u pogrešnom smjeru). Premda će se u praksi često raditi o dogovoru između počinitelja prethodnog kaznenog djela i naknadnog pomagača, djelo će postojati i bez takvog dogovora, pa i u situacijama u kojima počinitelj prethodnog kaznenog djela nije svjestan odnosno niti ne zna da mu netko postdeliktno pomaže. Okolnost da je pomagač za

79 Derenčinović, D. u Cvitanović et al., op. cit. u bilj. 68, str. 435.

80 Bačić, F., Pavlović, Š., op. cit. u bilj. 74, str. 1047.

81 Neprijavljivanje pripremanja kaznenog djela čini ona osoba koja zna da se priprema počinjenje kaznenog djela za koje je propisana kazna zatvora pet godina ili teža i to ne prijavi u vrijeme kad je još bilo moguće spriječiti njegovo počinjenje, a djelo bude pokušano ili počinjeno.

82 Usp. Derenčinović, D. u Cvitanović et al., op. cit. u bilj. 68, str. 430.

83 Bačić, F., Pavlović, Š., op. cit. u bilj. 74, str. 1048. 
svoje radnje primio novac ili kakvu drugu korist ne utječe na kvalifikaciju djela, no može biti od utjecaja na odmjeravanje kazne. ${ }^{84}$ Ovo kazneno djelo u literaturi se još naziva i kaznenim djelom podržavanja odnosno jatakovanja. Ovdje se radi o kaznenom djelu koje se nalazi u Posebnom dijelu Kaznenog zakona, dok bi se radilo o sudioništvu u smislu Općeg dijela KZ-a u situaciji naknadnog djelovanja, no samo pod uvjetom da je ono unaprijed obećano. Naime, unaprijed obećanim prikrivanjem pomagač je dao kauzalni doprinos počinjenju takvog kaznenog djela ${ }^{85} \mathrm{Za}$ razliku od pomaganja, kao jednog od oblika sudioništva kod kojeg se radnje pomagača poduzimaju kako bi počinitelju olakšalo počinjenje kaznenog djela kod kaznenog djela čl. 303. KZ-a, počinitelju se nakon počinjenog kaznenog djela pomaže kako bi izbjegao kazneni progon i da ne bude otkriven i uhićen. ${ }^{86}$ Hrvatski zakonodavac je odlučio kriminalizirati postdeliktno pomaganje samo kod težih kaznenih djela kod kojih je propisana kazna zatvora od pet godina ili teža.

Postavlja se pitanje razlike između kaznenog djela prikrivanja iz čl. 244. KZ-a i čl. 303. KZ-a. Unatoč sličnostima, postoje i određene razlike između ovih kaznenih djela, a one se sastoje u činjenici što je kazneno djelo prikrivanja imovinsko kazneno djelo, dok se kod čl. 303. KZ-a radi o bilo kojem kaznenom djelu uz uvjet da je za njega propisana kazna zatvora od pet godina ili teža. Kod kaznenog djela iz čl. 303. radi se o prikrivanju stvari, ali ne kako bi se pribavila imovinska korist nego kako bi se počinitelju pomoglo da ne bude otkriven. Kod kaznenog djela prikrivanja radi se o izričitoj supsidijarnosti odnosno primijenit će se ovo kazneno djelo ako time nije počinjeno neko drugo kazneno djelo za koje je propisana teža kazna.

U dio opisa radnje počinjenja ,ili na drugi način pomaže“, s obzirom na supsidijarnu narav ovoga kaznenog djela, ulaze samo one radnje pomoći počinitelju nakon počinjenja kaznenog djela koje već same za sebe nisu obilježje bića nekog drugog kaznenog djela. Neprijavljivanje počinjenog kaznenog djela za koje je propisana kazna do deset godina ne ulazi u zakonski opis kaznenog djela neprijavljivanja počinjenog kaznenog djela te se može otvoriti pitanje je li takvo ponašanje kažnjivo kao oblik pomoći počinitelju nakon počinjenog kaznenog djela. Ako bismo prihvatili tumačenje prema kojem se pomoć počinitelju nakon počinjenja kaznenog djela može počiniti samo činjenjem, tada bi jasno proizlazilo da neprijavljivanje počinjenog kaznenog djela za koje je propisana kazna zatvora do deset godina nije kažnjivo ni prema ovoj odredbi. Međutim, ovo kazneno djelo, pomoć počinitelju nakon počinjenja kaznenog djela sadrži generalnu klauzulu koja ne isključuje sama po sebi mogućnost da se radnja pomoći nakon počinjenja kaznenog djela počini i nečinjenjem što bi onda teoretski moglo obuhvatiti i neprijavljivanje lakšeg kaznenog djela. Ipak, prema gramatičkom tumačenju čl. 302, može se zaključiti da je očito intencija zakonodavca da ne kažnjava one osobe koje ne prijave počinjenje kaznenog djela za koje je propisana kazna zatvora manja od deset godina iako se takva radnja može podvesti pod opis kaznenog djela pomoć počinitelju

84 Derenčinović, D. u Novoselec, P. (ur.), op. cit. u bilj. 70, str. 352.

85 Derenčinović, D. u Cvitanović et al., op. cit. u bilj. 68, str. 437.

86 Pavlović, Š., op. cit. u bilj. 71, str. 653. 
nakon počinjenja kaznenog djela, te bi suprotno tumačenje bilo kontradiktorno. Isto tako, ako uzmemo u obzir činjenicu da radnje počinjenja koje se supsumiraju pod generalnu klauzulu moraju po svom tipu odgovarati prethodno nabrojenim radnjama u zakonskom opisu kaznenog djela prije uporabe generalne klauzule, tada bismo došli do zaključka kako se pod generalnu klauzulu ,ili na drugi način pomaže“ mogu podvesti samo radnje činjenja jer je prethodno pet nabrojenih načina počinjenja u zakonskom opisu navedeno u obliku činjenja ${ }^{87}$ Stoga se neprijavljivanje počinjenog kaznenog djela može razmatrati kao svojevrsno primarno ili čak specijalno kazneno djelo u odnosu na pomoć počinitelju nakon počinjenja kaznenog djela.

Više radnji pomaganja predstavljat će jedno kazneno djelo. Ovo kazneno djelo je akcesorno što pretpostavlja prethodno počinjenje drugoga kaznenog djela, ono slijedi to drugo već počinjeno kazneno djelo. ${ }^{88}$ To prethodno djelo može biti i jedno djelo jatakovanja, što znači da je moguće jatakovanje i u odnosu na djelo jatakovanja. ${ }^{89}$ Bitno je da su prethodno djelo i počinitelj u vrijeme poduzimanja jataštva kažnjivi. Stoga su oprost, odnosno pomilovanje oslobođenjem od kaznenog progona ili situacija kada se kazneni progon ne može poduzeti zbog zastare, ili ako postoje druge okolnosti koje isključuju kazneni progon, irelevantni za jatakovanje. Kazneni progon i kažnjavanje za djelo jatakovanja može se poduzeti neovisno o tome je li poduzet progon za prethodno djelo jer ne postoji akcesornost u procesnom smislu. ${ }^{90}$ Jatak je počinitelj jednog novog, posebnog samostalnog kaznenog djela. Sadržaj neprava ovog novog samostalnog kaznenog djela nije sudjelovanje u prethodnom djelu, već otežavanje ili onemogućavanje kaznenopravne reakcije prema počinitelju kaznenog djela. Iz dikcije ove odredbe ne proizlazi da postojanje ovog djela ovisi o tome je li počinitelj, čije djelo se prikriva, pravomoćno osuđen ili nije. ${ }^{91}$

Moguć je stjecaj različitih oblika pomoći, ali se uvijek radi o jednom kaznenom djelu, s tim da će se postojanje različitih oblika pomoći u postupku odmjeravanja kazne uzeti kao otegotna okolnost. Biću ovog djela odgovaraju radnje koje znače izravnu neposrednu pomoć počinitelja da ne bude otkriven, odnosno da se ne izvrši izrečena sankcija. ${ }^{92}$ Počinitelj ovog djela ne može biti osoba koja je na bilo koji način sudjelovala u počinjenju prethodnog djela. Osobe koje su sudjelovale u počinjenju prethodnog djela ne mogu biti ni sudionici u ovom kaznenom djelu. ${ }^{93}$

Prema stavku 5. nema kaznenog djela ako postoji osobna povezanost počinitelja ovoga kaznenog djela s osobom kojoj je počinitelj pružio pomoć nakon počinjenja djela. Druge osobe na koje se odnosi profesionalna tajna (odvjetnik, vjerski

87 Ipak ne treba smetnuti s uma ni odredbe Općeg dijela KZ-a, pa ako je netko primjerice na drugi način bitno pridonio počinjenju kaznenog djela u smislu supočiniteljstva, tada je potrebno potvrditi i radnju nečinjenja kao počiniteljsku radnju pod uvjetom da se radnja nečinjenja ne sastoji od neprijavljivanja jer neprijavljivanje kaznenih djela kod kojih je propisana kazna zatvora do deset godina nije kažnjivo.

88 Pavlović, Š., op. cit. u bilj. 71, str. 654; Garačić, A., Novi Kazneni zakon, Zagreb, 2013., str. 594.

89 Pavlović, Š., op. cit. u bilj. 71, str. 654.

90 Bačić, F., Pavlović, Š., op. cit. u bilj. 74, str. 1050.

91 Garačić, A., op. cit., u bilj. 88, str. 594.

92 Pavlović, ک̌S., op. cit. u bilj. 71, str. 654.

93 Ibid., str. 655. 
ispovjednik...) ne mogu, dakle, koristiti ovu zakonsku pogodnost već samo osoba koja je počinitelju prethodnog djela bračni drug, koja s tim počiniteljem živi u izvanbračnoj zajednici, koja mu je rođak po krvi u pravoj liniji, brat ili sestra, posvojitelj ili posvojenik. Ako su osobe iz stavka 5 bile sudionici u djelu jatakovanja treće osobe u odnosu na počinitelja prethodnog djela s kojim one stoje u odnosima opisanim u ovome stavku, ostaju nekažnjene za to svoje djelo ${ }^{94}$ Štoviše, odgovornost će postojati za ovo kazneno djelo i kad osoba kojoj se pruža pomoć naknadno bude oslobođena jer je i u tom slučaju pružanjem pomoći takvoj osobi ometen normalni rad pravosuđa. ${ }^{95}$ Iz navedenog možemo zaključiti i da vjerski ispovjednik ili klerik koji pruža pomoć počinitelju nakon počinjenja kaznenog djela u smislu sprečavanja normalnog funkcioniranja pravosudnog sustava, može biti počinitelj ovog kaznenog djela.

\subsection{Neovlašteno otkrivanje profesionalne tajne (čl. 145. KZ-a)}

Da bismo razumjeli nepovredivost ispovjedne tajne u kanonskom pravu i u kontekstu kaznenog zakonodavstva Republike Hrvatske, potrebno je analizirati kazneno djelo neovlaštenog otkrivanja profesionalne tajne u kaznenom pravu. Naime, postavlja se pitanje je li i pod kojim uvjetima dopušteno otkriti ispovjednu tajnu s obzirom na to da zakonodavac u RH pod određenim pretpostavkama dopušta otkrivanje profesionalne tajne.

Kazneno djelo neovlaštenog otkrivanja profesionalne tajne sastoji se od svakog ponašanja određene osobe kojim se tajna prenosi, iskazuje ili daje do znanja drugome. Profesionalnu tajnu može se otkriti ne samo verbalnim iskazom već i (namjernim) ostavljanjem nezaštićenog tajnog dokumenta na mjestu gdje je dostupan neovlaštenim trećim osobama, objavljivanjem podataka u stručnom ili znanstvenom radu i na drugi način. Tajna je podatak o osobnom ili obiteljskom životu koji je počinitelju ovoga djela povjeren u obavljanju njegova zvanja. ${ }^{96}$ Objekt tajne mora biti istinit i nepoznat. ${ }^{97}$ Neistinita tvrdnja ili podatak nisu tajna. Vlasnik ili posjednik tajne nastoji nešto očuvati od indiskrecije, pri čemu mu pomaže i kaznenopravna reakcija. Podatkom se može smatrati dokument, odnosno svaki napisani, umnoženi, nacrtani, slikovni, tiskani, snimljeni, fotografirani, magnetni, optički, elektronički ili bilo koji drugi zapis podataka, saznanje, mjera, postupak, predmet, usmeno priopćenje ili informacija koja s obzirom na svoj sadržaj ima važnost povjerljivosti i cjelovitosti za svog vlasnika. Śtiti se intimnost osobe, a preko nje i potreba pravilnog funkcioniranja određenih javnih poziva i djelatnosti. Ovdje se radi o dvostrukom jednosmjernom odnosu..$^{98}$ Odnos djelatnika ovih službi i građanina temelji se na međusobnom povjerenju, uključujući jamstvo da će osobna tajna biti poštovana.

\footnotetext{
94 Ibid.

95 Derenčinović, D. u Novoselec, P. (ur.), op. cit. u bilj. 70, str. 351

96 Derenčinović, D. u Cvitanović et al., op. cit. u bilj. 68, str. 175.

97 Bačić, F., Pavlović, Š., op. cit. u bilj. 74, str. 548.

98 Pavlović, Š., op. cit. u bilj. 71, str. 302.
} 
Kod ovog kaznenog djela saznata činjenica pri obavljanju poziva nije pristupačna širem krugu osoba. ${ }^{99}$

Ovo kazneno djelo je pravo posebno kazneno djelo jer ga mogu počiniti samo one osobe kojima je određeni podatak povjeren u obavljanju njihova zanimanja. Ovdje je zadržana generalna klauzula pa će za ovo djelo odgovarati i druga osoba kojoj je tajni podatak povjeren vezano uz njeno zvanje. Otkrivanje tajne mora biti neovlašteno. Pojam neovlašteno i kod ovog djela ima dvojaku funkciju. Uz to što ukazuje na postojanje mogućih razloga isključenja protupravnosti u drugim postupcima, neovlaštenost prvenstveno upućuje na nepostojanje suglasnosti osobe na čiji se osobni i obiteljski život izneseni podatak odnosi. Ovo kazneno djelo neće postojati ako su otkriveni podaci čije držanje u tajnosti nije važno za očuvanje čovjekova intimiteta (objektivno beznačajni podaci). ${ }^{100}$

Kao razlog isključenja protupravnosti propisano je otkrivanje tajne počinjeno u javnom interesu ili interesu druge osobe koji je „pretežniji“ od interesa čuvanja tajne, kao što je interes otkrivanja nekog kaznenog djela ili zaštita osoba od opasne i zarazne ili spolne bolesti. Ovdje sukobljeni interes javnosti odnosno druge osobe s jedne strane i interes čuvanja tajne, odnosno, zaštite privatnosti s druge strane treba vagati in concreto ovisno o okolnostima pojedinog slučaja. ${ }^{101}$ Protupravnost će biti isključena i kada drugi zakoni od osobe koja je inače dužna čuvati profesionalnu tajnu zahtijevaju iznošenje podataka iz osobnog i obiteljskog života, odnosno tajne koja joj je povjerena u obavljanju njezine djelatnosti. To nužno proizlazi iz jedinstva pravnog poretka. ${ }^{102}$

Počinitelj mora postupati s namjerom tako da je svjestan povjerljive naravi podataka kao i mogućnosti da svojim ponašanjem taj podatak otkrije drugoj osobi, te na to mora makar pristati. Osoba koja otkrije tajnu slučajno, nepažnjom, tj. iz nehaja, ne čini kazneno djelo iz čl. 145. KZ-a. ${ }^{103}$

\subsubsection{Kaznenopravni status vjerskog ispovjednika u odnosu na ispovjednu tajnu}

S obzirom na to da Kazneni zakon dopušta otkrivanje profesionalne tajne kod zaštite pretežnijeg interesa, otvara se pitanje vrijedi li ista odredba KZ-a i za vjerskog ispovjednika u odnosu na ispovjednu tajnu. Ovdje upravo može biti sporno pitanje pretežnijeg interesa otkrivanja od čuvanja tajne. Da bismo to mogli ispravno procijeniti, najprije je potrebno definirati ispovijed u kontekstu kanonskog prava. Zakonik kanonskog prava u Kan. $983-\S 1$ propisuje da je sakramentalni pečat nepovrediv, stoga ispovjednik ne smije riječima ni na bilo koji drugi način ni zbog bilo kojeg razloga nikako odati pokornika. § 2 propisuje da je tajnu obvezan čuvati

\footnotetext{
99 Bačić, F., Pavlović, Š., op. cit. u bilj. 74, str. 549.

100 Ibid.

101 Garačić, A., op. cit., u bilj. 88, str. 343.

102 Derenčinović, D. u Cvitanović et al., op. cit. u bilj. 68, str. 177.

103 Ibid.
} 
i tumač, ako ga ima, kao i svi drugi do kojih je na bilo koji način iz ispovijedi doprlo znanje o grijesima. Naime, ono što se događa u sakramentu pomirenja ulazi u božansko područje i tu treba i ostati. Ni najvažniji interesi bilo privatnog bilo javnog dobra ne mogu opravdati povredu sakramentalnog pečata. ${ }^{104}$ Pod ispovjednu tajnu spada također i sadržaj ispovijedi ako je odrješenje odgođeno ili uskraćeno. Ako bi ispovjednik izravno povrijedio sakramentalni pečat, upao bi u izopćenje unaprijed izrečeno pridržano Apostolskoj Stolici, a ako bi to pak učinio neizravno, treba biti kažnjen prema težini zločina. ${ }^{105}$ Nema nikakve razlike ni vezano za težinu grijeha, odnosno radi li se o lakšem ili težem grijehu.

Kan. $984-\S 1$. ispovjedniku posve zabranjuje služiti se na štetu pokornika znanjem do kojeg je došao u ispovijedi, i kad je isključena svaka pogibelj otkrivanja. No očigledno je da po dužnosti jednakosti i po smislu za poštovanje časti prema svećeniku ispovjedniku, on treba poštovati šutnju o tome što mu je ispovjednik, pouzdavajući se u njegovu diskretnost, očituje unutar sakramentalne ispovijedi. ${ }^{106}$ To znači da suprotno Kaznenom zakonu, Zakonik kanonskog prava ne dozvoljava otkrivanje ispovjedne tajne ni kod pretežnijeg interesa. Ovdje je potrebno vidjeti postoji li kolizija odredbi crkvenog i državnog prava. Naime, sudovi u Republici Hrvatskoj sude na temelju Ustava, zakona, međunarodnih ugovora i drugih važećih izvora prava. Čl. 134. Ustava RH propisuje da međunarodni ugovori koji su sklopljeni i potvrđeni u skladu s Ustavom i objavljeni, a koji su na snazi, čine dio unutarnjega pravnog poretka Republike Hrvatske, a po pravnoj su snazi iznad zakona. Njihove se odredbe mogu mijenjati ili ukidati samo uz uvjete i na način koji su u njima utvrđeni, ili suglasno općim pravilima međunarodnog prava.

Iz članka 1. Ugovora o pravnim pitanjima između Svete Stolice i Republike Hrvatske proizlazi da su Država i Katolička crkva, svaka u svom poretku, neovisne i samostalne. Članak 8. st. 2. propisuje da je ispovjedna tajna u svakom slučaju nepovrediva. ${ }^{107}$ Načelo apsolutne nepovredivosti ispovjedne tajne proizlazi dakle iz međunarodnog ugovora koji je po svojoj pravnoj snazi iznad Kaznenog zakona. Treba naglasiti da se ova odredba Ugovora primjenjuje samo u slučaju saznanja činjenice u okviru ispovjedne tajne ili vezano za ispovjednu tajnu.

S obzirom na to da je i Europska konvencija za zaštitu ljudskih prava i temeljnih sloboda također međunarodni ugovor i regulira pitanje slobode vjeroispovijedi kao

104 Berljak, M., Sakramenti ozdravljenja, Zagreb, 2004., str. 59.

105 Ivan Pavao II., Sakrament pokore, Sedam govora i jedno apostolsko pismo Ivana Pavla II., Zagreb, 1997., str. 57.

106 Berljak, M., op. cit. u bilj. 104, str. 61.

107 Tekst o nepovredivosti ispovjedne tajne nalazi se i u drugim međunarodnim ugovorima Svete Stolice, kao primjerice sa Španjolskom, Njemačkom, Austrijom, Portugalom, Italijom i Gabonom. U međunarodnom ugovoru sa Spanjolskom sadržaj povjerljivosti je čak i širi od ispovjedne tajne jer ni u jednom slučaju suci neće moći tražiti od klerika i redovnika obavijesti o osobama ili predmetima koje su doznali vršeći svoju službu (čl. 2. § 2). Ugovor s Njemačkom spominje povjerljivost informacija koje su saznate u okviru dušobrižništva, odnosno obavljanja duhovne službe (čl. 9.), a ne samo u okviru ispovjedne tajne. Primjerice, ugovor Svete Stolice i Poljske ne sadrži klauzulu tajnosti ni u okviru dušobrižništva, a ni u okviru ispovjedne tajne. Eterović, N.: Ugovori između Svete Stolice i Republike Hrvatske, povijest nastanka i komentar, Zagreb, 2001., str. 167-168. 
i ograničenje slobode vjeroispovijedi, postavlja se pitanje odnose li se ograničenja slobode vjeroispovijedi, navedena u EKLJP-u, i na ispovjednu tajnu, odnosno, može li nepovredivost ispovjedne tajne biti ograničena na temelju Konvencije. Europska konvencija za zaštitu ljudskih prava i temeljnih sloboda propisuje u čl. 9.1. st. 1. da svatko ima pravo na slobodu mišljenja, savjesti i vjeroispovijesti, te da to pravo uključuje slobodu da se promijeni vjeroispovijed ili uvjerenje i slobodu da se pojedinačno ili u zajednici s drugima, javno ili privatno, iskazuje svoju vjeroispovijed ili uvjerenje bogoslužjem, poučavanjem, praktičnim vršenjem i obredima. Isti članak u stavku 2. propisuje da će se sloboda iskazivanja vjeroispovijedi ili uvjerenja podvrgnuti samo takvim ograničenjima koja su propisana zakonom i koja su u demokratskom društvu nužna radi interesa javnog reda i mira, zaštite javnog reda, zdravlja ili morala, ili radi zaštite prava i slobode drugih. S obzirom na to da postoji mogućnost kolizije između EKLJP-a i Ugovora sa Svetom Stolicom, jer su i EKLJP i MU po pravnoj snazi jednaki u RH, ovdje treba uzeti u obzir da je Ugovor sa Svetom Stolicom lex specialis u odnosu na Konvenciju te također da je Ugovor sa Svetom Stolicom lex posterior u odnosu na Konvenciju ${ }^{108}$ pa treba dati prednost Ugovoru sa Svetom Stolicom.

\section{ZAKLJUČAK}

Načelo neovisnosti kanonskog i državnog kaznenog postupka te načelo međusobne suradnje temeljne su odrednice odnosa države i Crkve u području kaznenog prava iz kojih proizlazi dužnost prijave kaznenih djela počinjenih od strane klerika te dužnost suradnje tijekom postupka neovisno o prijavi, pokretanju, vođenju te ishodu kanonskog kaznenog postupka protiv iste osobe klerika. Ipak, u ostvarenju navedenih načela potrebno je voditi računa o granicama te suradnje kakvu predstavlja načelo nepovredivosti ispovjedne tajne koje zakonodavstvo Republike Hrvatske priznaje u apsolutnom opsegu. Tako vjerski ispovjednik ne može odgovarati za kazneno djelo neprijavljivanja pripremanja kaznenog djela kao ni za neprijavljivanje počinjenog kaznenog djela ako je o njima saznao tijekom ispovijedi. Iako Kazneni zakon dopušta otkrivanje sadržaja profesionalne tajne u slučaju zaštite pretežnijeg interesa, to se ne odnosi na ispovjednu tajnu s obzirom na to da je apsolutna nepovredivost ispovjedne tajne zajamčena Ugovorom o pravnim pitanjima kao aktom više pravne snage. Osim u pogledu apsolutne nesposobnosti za svjedočenje vjerskog ispovjednika u odnosu na sadržaj ispovijedi koja proizlazi

108 Ovdje se uzima u obzir vrijeme donošenja Konvencije, a ne trenutak ratifikacije od strane RH. Naime, u presudi ESLJP-a Strelec, Kessler i Krenz protiv SR Njemačke utvrđeno je da se načelo zakonitosti promatra od trenutka donošenja međunarodnih dokumenata na razini svijeta, odnosno od trenutka kad su navedene odredbe postale običajno pravo prihvaćeno nacionalnim pravnim sustavom. Strelec, Kessler i Krenz protiv SR Njemačke, 34044/96, 35532/97, 44801/98 od 22. ožujka 2001. Slijedom navedenoga, citirani sadržaj odredbe EKLJP-a identičan je čl. 18. u vezi s čl. 29. st. 2. Opće deklaracije o ljudskim pravima od 10. prosinca 1948. Iz navedenoga je vidljivo da je ispovjedna tajna zaštićena pravnom snagom međunarodnog ugovora, dok je ograničenje vjerskih sloboda pa i ispovjedne tajne prema navedene dvije Konvencije moguće aktom zakonske pravne snage. Akt zakonske pravne snage uvijek je niži od međunarodnog ugovora. 
iz ovog načela, a koju Zakon o kaznenom postupku dosljedno propisuje te obveze obavještavanja crkvenih vlasti o istrazi protiv klerika, pravni položaj klerika, bilo da se pojavljuje u svojstvu okrivljenika, svjedoka, oštećenika tijekom kaznenog postupka, ne razlikuje se od pravnog položaja drugih osoba u istom svojstvu.

Premda primjena načela nepovredivosti ispovjedne tajne može ograničiti u određenim aspektima mogućnosti otkrivanja i kažnjavanje počinitelja kaznenih djela, nužnost dosljednog i apsolutnog poštovanja ovog načela ne proizlazi samo iz međunarodnog ugovora već i iz činjenice da bi se njegovim dokidanjem nepovratno narušilo temeljno povjerenje građana vjernika u Crkvu, a s druge strane, pripadnike klera dovelo u teške moralne i pravne dvojbe. Naposljetku valja zaključiti da se pravodobnim prijavljivanjem kaznenih djela počinjenih od strane klerika nadležnim državnim tijelima te izraženom spremnošću na suradnju s državnim tijelima, a u okvirima spomenutih granica, pridonosi učinkovitosti kaznenog postupka s jedne strane, a s druge strane osnažuje se povjerenje vjernika u Crkvu kao nadnaravnu duhovnu tvorevinu i otajstvo, te povjerenje svih građana u Crkvu kao društvenu instituciju i vjersku zajednicu.

\section{SOME ISSUES ON COOPERATION OF STATE AND CHATOLIC CHURCH IN THE FIELD OF CRIMINAL LAW}

The subject of this paper is an analysis of the relationship between the state and the Church in the field of criminal law. After presenting the basic principles of state-church relations, the authors look more closely at the issue of state-church cooperation in criminal proceedings in relation to the obligation to report crimes, the obligation to inform church authorities about conducting investigation against clerics, and the specific position of a religious confessor in criminal proceedings as a witness. The fourth chapter examines the boundaries of cooperation between the state and the Church in the context of the Criminal Code, ie the criminal offenses of not reporting a committed crime and helping the perpetrator after the crime has been committed. It also analyzes the scope of the principle of inviolability of seal of confession in the context of criminal law, in particular, the relation to the criminal offense of unauthorized disclosure of professional secrecy. The authors conclude on the necessity of effective cooperation between the state and the Church, timely reporting of crimes, and the obligation of absolute respect for the principle of inviolability of seal of confession.

Key words: crime report, criminal procedure, canonical procedure, investigation, seal of confession 